\title{
НЕКОТОРЫЕ РАЗМЫШЛЕНИЯ О МЕТОДОЛОГИИ НАУЧНЫХ РЕВОЛЮЦИЙ В ЭКОНОМИЧЕСКОЙ ТЕОРИИ
}

\author{
(c) 2021 Нифаева Ольга Владимировна \\ кандидат экономических наук, доцент кафедры «Производственный менеджмент» \\ Брянский государственный технический университет, Россия, Брянск \\ E-mail: olganifaeva@yandex.ru
}

В статье рассматриваются предпосылки революционных изменений в истории экономической теории с точки зрения философии науки. Цель статьи заключается в анализе наиболее распространенных подходов к трактовке научных революций и их применения к истории экономической мысли. Систематизация признаков научных революций позволяет проследить некоторые особенности революционных преобразований в экономической теории, которые сопровождаются изменениями в восприятии учеными экономической реальности. С этих позиций в статье пересматривается сущность маржиналистской революции. Автор также аргументирует положение о кумулятивноциклическом характере развития экономической науки.

Ключевые слова: этика, онтология, экономическая методология, научная революция, история экономических учений.

История теоретической экономической науки может быть описана посредством чередования революционных и эволюционных стадий ее развития. Введение в научный оборот термина «научная революция», как правило, связывают с именем Т.Куна, работа которого «Структура научных революций» вышла в 1962 году, хотя с позиций исторической справедливости нельзя не отметить то, что сам термин «научная революция» можно встретить уже в трудах К.А.СенСимона [5]. Согласно точке зрения Т. Куна, научная революция следует за этапами нормальной и экстраординарной науки. В работе Т.Куна отсутствует исчерпывающий перечень критериев свершения научной революции. Однако в процессе изучения его работы можно обобщить следующие симптомы революционных изменений. Первый и наиболее существенный признак коренных преобразований в науке заключается в трансформации видения изучаемой реальности, онтологии, представлений ученых о мире. Другой признак научной революции связан с тем, что ученые начинают обращаться к философским и методологическим проблемам своей науки, а именно начинают пересматривать стандарты постановки и решения теоретических проблем. Указанные выше изменения в науке часто происходят параллельно с важными изменениями исторических и культурных условий, если рассматривать науку как социальный институт [4].
Наряду с Т. Куном философские аспекты эволюции различных наук рассматривали многие отечественные и зарубежные ученые. В частности в философии и методологии науки говорят о развитии теоретического знания как о смене научно-исследовательских программ (И.Лакатош), идеалов естественного порядка (С. Тулмин), основных тематов (Дж.Холтон), исследовательских традиций (Л.Лаудан) [6]. Одна из наиболее известных попыток периодизации науки в отечественной философии была предпринята В.С.Степиным. Его крупнейшая работа, посвященная этой проблеме, носит название «Теоретическое знание». В отличие от Т.Куна В.С.Степин разработал более четкие и структурированные критерии научных революций. По его мнению, революция в науке означает радикальную трансформацию оснований теории. В структуру этих оснований входят как дисциплинарная онтология, так и философские идеалы и нормы научности, существующие в условиях определенного социально-культурного окружения. Термин «дисциплинарная онтология» в некоторой степени (по крайней мере, в том смысле, в котором он упомянут выше) весьма близок термину Т. Куна «парадигма», хотя для термина «парадигма», в том числе в работе самого Т. Куна, ученые находят множество определений, считая этот термин слишком многозначным. В большинстве случаев Т.Кун определял парадигму как признаваемые учеными дости- 
жения, служащие в качестве модели постановки и решения теоретических проблем. Ключевой критерий научных революций В. С. Степин вслед за Т.Куном также связывал с преобразованием онтологических, парадигмальных представлений ученых.

Следуя взглядам Т. Куна и В.С.Степина, можно сказать, что многие научные дисциплины, прежде всего, общественные и гуманитарные, отличаются длительными периодами преобразования канонов научного исследования; революции в науке не происходят за один день, а могут подготавливаться и разворачиваться довольно долгое время. В таких длительных периодах в истории экономической мысли выделяют несколько этапов (как правило, два) в лице предшественников революции и самих «революционеров». На первом этапе революционные изменения подготавливаются отдельными учеными, в их трудах появляются новые теоретические и методологические идеи, которые могут оставаться невостребованными, так как не соответствуют превалирующим в то время идеалам и нормам научности, а главное не вписываются в имеющиеся онтологические представления, не в полной мере отвечают текущим экономическим реалиям и потребностям практики. Однако по мере трансформации экономической реальности и накопления теоретического и фактического материала новые идеи становятся более распространенными, начинают пользоваться вниманием ученых, можно сказать, заново переоткрываются, иногда в прямом смысле слова (ведь «революционеры», действительно, могут ничего не знать об идеях своих предшественников). О научной революции объявляют тогда, когда мы можем наблюдать совпадение того, что происходит в реальности, и того, что предлагают ученые, то есть когда то или иное знание или идею уже невозможно отвергать, так как они соответствуют запросам времени.

Аргументы в пользу двухэтапного характера научных революций в экономической теории особенно справедливы в отношении событий, которые происходили в конце XIX века и связаны с так называемой маржиналистской революцией, 150-летие которой отмечается в этом году, так как «революционные» работы К.Менгера «Основания учения о народном хозяйстве» (в русском переводе - «Основания политической экономии») и У.С.Джевонса «Теория политической экономии» увидели свет в 1871 году, а главная работа Л.Вальраса «Элементы чистой политической экономии» была опубликована в 1874 году. Первый этап этой революции традиционно связывают с именами Г. Госсена, И. фон Тюнена, А. Курно, Ж.Дюпюи. Тем не менее, их идеи не привлекли должного внимания в эпоху господства классической политической экономии [3]. Как правило, революционное значение маржинализма связывают со следующими утверждениями. В первую очередь благодаря маржинализму в предметной области исследования экономической науки стали делать акцент не только на сфере производства, но и на сфере обмена, товарообращения и потребления. Во-вторых, активное применение количественных (формализованных) методов исследования происходило наряду с упрощением модели экономического поведения и сведением целей хозяйствования к максимизации удовольствия или полезности. В-третьих, математические методы способствовали приданию экономической науке облика точной дисциплины, в то же время подстраивая под себя научную картину экономического универсума, так как количественными методами по определению можно исследовать весьма ограниченный пласт экономических феноменов. Аналогии из естественных и точных наук стимулировали появление и укрепление позиций в экономической науке аппарата предельных величин, а также таких категорий, как редкость, оптимизация, равновесие, которые, по мнению ряда зарубежных исследователей, на долгое время стали ключевыми экономическими категориями. Существует точка зрения, что активное применение математических методов, действительно, не только укрепило статус экономической науки, но и привело к значительному упрощению многих экономических феноменов, их приспособлению под имеющиеся математические методы $[8,10]$. Несмотря на то, что понятие «маржиналистская революция» прочно вошло в лексикон историков экономической мысли и в учебники по экономической теории и истории экономических учений, не все ученые разделяют точку зрения о революционном характере маржинализма. Можно сказать, что маржинализм представлял собой революцию метода экономической науки, а не теории как таковой. Ведь, по сути, как отмечают некоторые исследователи, маржинализм во многом представлял собой математизированное переложение идей И.Бентама об арифме- 
тике наслаждений и страданий. Представители инженерно-математического типа мышления, пришедшие в экономическую науку, переводили экономические феномены на понятный им язык классической механики и линейной термодинамики. Ряд ученых полагает, что маржинализм позволил формализовать такие явления, как удовольствие от очередной чашки кофе, но он оказался безразличен и бессилен в отношении анализа многих острых социальных проблем второй половины XIX века [2, 7, 9, 10].

С онтологической точки зрения, следует отметить, что маржинализм основывался на натуральной философии эпохи классицизма науки с ее ориентацией на закрытые, равновесные системы, состоящие из ограниченного числа простых элементов. И если мы вновь обратимся к критериям научных революций, разработанным Т.Куном и В.С.Степиным, то окажется, что маржинализм не привел к существенному изменению оснований теоретического знания, которые могли бы способствовать переходу к новому этапу развития науки (то есть к научной революции). Еще один весьма интересный факт заключается в том, что наступлению революции в науке, как правило, предшествуют методологические споры, крупные дискуссии в области методологии, разрешение которых в конечном итоге и выливается в революционный пересмотр методологии. В отношении же маржиналистской революции такой спор последовал уже после нее (между представителями австрийской и кембриджской школы маржинализма и экономистами-историками Великобритании и Германии). Знаменитый «спор о методах», скорее, был не прологом, а послесловием к маржиналистской революции еще и потому, что классическая политическая экономия с самого начала подвергалась критике (экономистами романтиками и утопистами с начала XIX века) за излишнюю абстрактность, космополитичность, статичность, отрыв от реальных общественных проблем. Вследствие этого в «споре о методах» маржиналистам приходилось разъяснять и оправдывать свои оторванные от практики умозаключения; они были вынуждены защищаться от критики в чрезмерном упрощении науки, подражании естествознанию и даже большей степени абстрактности, чем была присуща классической политической экономии.

Таким образом, существуют аргументы как «за», так и «против» маржиналистской революции, поэтому в вопросе о характере этого собы- тия в истории экономической мысли все еще не поставлена точка. По всей вероятности, можно предположить, что маржиналистская революция была так называемой мини-революцией (в терминологии В.В.Казютинского) и революцией, основанной на междисциплинарной прививке (в терминологии В.С.Степина). Такими терминами можно обозначить научные революции, которые приводят не к слому всей структуры оснований науки, а лишь отдельных ее элементов за счет заимствования методов других наук (в случае маржиналистской революции речь идет об активном внедрении математических методов, прежде всего, методов анализа предельных величин). Маржиналистская революция не привела к радикальным изменениям в основаниях науки, а если принять во внимание первый и важнейший критерий научной революции - трансформацию дисциплинарной онтологии $[1,6]$, то в случае маржиналистской революции существенные преобразования дисциплинарной онтологии также не произошли (если не считать значительного упрощения экономической реальности и перевода принципов утилитаризма на математический язык). Как указывал Й.Шумпетер в своей «Истории экономического анализа», восприятие маржиналистами экономической реальности существенно не отличалось от экономического видения времен А. Смита и Д.Рикардо [11]. В работах и классиков политической экономии, и маржиналистов господствовала одна и та же продуктовая (дисциплинарная) онтология и механистическая (общенаучная) онтология, в соответствии с которыми экономика рассматривалась как идеальный механизм, машина, а экономическое благосостояние трактовалось преимущественно с материальной точки зрения $[1,6]$.

Вопрос о научных революциях в экономической теории позволяет высказать еще несколько замечаний. Дело в том, что рост научного знания в экономической теории носит неравномерный, нелинейный характер. Это как раз очень хорошо видно на примере научных революций в экономической теории, результатом которых было как продвижение экономической науки вперед, так и выхолащивание идей ведущих ученых-экономистов. Такова судьба идей А.Смита, от которых остались только «невидимые руки» эгоизма и совершенной конкуренции, К. Маркса, чрезмерно критикуемого за излишний материализм и экономический детерминизм, Дж. М. Кейнса, математизация идей кото- 
рого привела к утрате этико-психологического содержания его достижений, и Т.Веблена, от которого до нас дошел лишь упрощенный подход к жонглированию эволюционно-биологической терминологией. Между тем, эти и другие крупнейшие представители экономической науки не всегда были приверженцами тех идей, которые в упрощенном виде попадали в учебники, а потом становились предметом критики. Причины упрощения, «смягчения», «сглаживания» значения революционных идей имеют ярко выраженный институционально-этический характер, в них велика роль идеологических, классовых, репутационных, корпоративных факторов. Как следствие, формируются условия для двухэтапного протекания научных революций в экономической теории. Революция объявляется после того, как революционное открытие сделано или принято не одним ученым. Идеи, опережающие время, не принимаются научным сообществом по причине высокой степени его консервативности и необходимости сохранения репутации и могут расцениваться как эксцентричные и чудаковатые. Когда же предвосхищения становятся очевидными (то есть предстают в развернутом виде, соответствующем экономической реальности), о них вспоминают, заново их открывают и провозглашают революцию. Таким образом, двухэтапный характер научных революций в экономической теории связан как с особенностями функционирования научного сообщества как социального института, так и с состоянием экономической реальности.

При этом автор считает необходимым отметить, что в результате научной революции рево- люционная идея распадается на две части. Одна часть, которая в меньшей степени противоречит устоявшимся представлениям и способна в виде ad hoc гипотезы или после корректировки быть включенной в мейнстрим, поглощается ортодоксальной экономической наукой. Другая часть временно получает развитие в неортодоксальной ветви, чтобы стать источником приращения научного знания в будущем. Здесь важно учитывать следующий социально-психологический момент: представители гетеродоксальных течений экономической мысли более открыты новым идеям и взаимодействию с другими науками, поскольку уже в некоторой степени подвергнуты остракизму, меньше боятся навредить своей репутации, выдвигая или принимая новые идеи. В результате идея, не получившая признание в момент своего возникновения, по мере все большего соответствия экономическим реалиям получает и большее признание и развитие, пока окончательно не станет частью ортодоксальной науки. Таким образом, экономическая теория продвигается вперед, хотя и с периодическим попятным движением. Развитие экономической науки, как и развитие экономической реальности, носит кумулятивно-циклический характер: имеет место как возвращение к одним и тем же идеям на схожих этапах экономического развития, так и приращение научного знания на фундаменте предыдущих достижений. В свою очередь научные революции являются результатом кумулятивного роста знания, синтеза идей или даже блестящего предвидения более ранних исследований в новых социально-экономических обстоятельствах.

\section{Библиографический список}

1. Ананьин О.И. Структура экономико-теоретического знания: методологический анализ.- М.: Наука, 2005.243 с.

2. Аникин А.В. Юность науки: Жизнь и идеи мыслителей-экономистов до Маркса.- М.: Политиздат, 1985.367 с.

3. Гловели Г.Д. История экономических учений.-М.: Юрайт, 2011.-742 с.

4. Кун Т., Лакатош И., Поппер К. Структура научных революций.- М.: АСТ, 2003.-605 с.

5. Сен-Симон К. А. Избранные сочинения: в 2 т. М.; Л.: АН СССР, 1948.

6. Степин В. С. Теоретическое знание.- М.: Прогресс-Традиция, 2000. - 744 с.

7. Hayek F. A. The Counter-Revolution of Science: Studies on the Abuse of Reason.- London; New York: The Free Press of Glencoe, 1952.-255 p.

8. Hodgson G. M. How Did Economics Get into Such a State? // Post-Autistic Economics Newsletter.-2001._ No. 8.P. 143-146.

9. McCloskey D. N. Max U vs. Humanomics: A Critique of Neo-Institutionalism// Journal of Institutional Economics. 2015.- Vol. 12.- No 1.- P. 1-27.

10. Mirowski P. Physics and the «Marginalist Revolution»// Cambridge Journal of Economics. - 1984. - No. 8. - P. 361-379.

11. Schumpeter J. A. History of Economic Analysis. London: Routledge, Taylor \& Francis e-Library, 2006.-1283 p. 